\title{
Investigate of Effective Factors on Extraction of Silver from Tailings of Lead Flotation Plant Using Thiourea Leaching
}

\author{
Bandehzadeh Masoud ${ }^{1}$, Aryanimehr Amir ${ }^{1}$, Rezai Bahram² \\ ${ }^{1}$ Department of Mining Engineering, Science and Research Branch, Islamic Azad University, Tehran, Iran \\ ${ }^{2}$ Department of Mining Engineering, Amirkabir University of Technology, Tehran, Iran \\ Email: "bandeh2000@gmail.com
}

Received 20 February 2016; accepted 22 May 2016; published 25 May 2016

Copyright (C) 2016 by authors and Scientific Research Publishing Inc.

This work is licensed under the Creative Commons Attribution International License (CC BY). http://creativecommons.org/licenses/by/4.0/

c) (7) Open Access

\begin{abstract}
In current paper, the effect of different factors on extraction of silver from tailings of lead flotation plant using thiourea leaching was studied. According to the mineralogical studies and chemical analysis taken from the tailings dam, the representative sample taken from there contained 30 ppm Ag and the minerals such as calcite, dolomite, barite, microcline, galena etc. In this research, the effects of iron(III) sulfate concentration, thiourea concentration, size and temperature onextraction of silver from Ravanj flotation plant tailings were analyzed using statistics design of experiment and DX7 software; and it was determined that iron(III) sulfate concentration and temperature were the most effective factors on the extraction of silver. The results showed that the best recovery obtained in particle size of 75 microns, $1 \mathrm{~kg} / \mathrm{m}^{3}$ thiourea concentration and $1 \mathrm{~kg} / \mathrm{m}^{3}$ iron(III) sulfate concentration in the temperature of $60^{\circ} \mathrm{C}$ for 2 hours.
\end{abstract}

\section{Keywords}

Thiourea (TU), Design Experimental (DX7), Formamidine Disulfide (FDS)

\section{Introduction}

Cyanidation has become the most popular method of gold and silver recycling from mineral resources because of the simplicity and economical reasons for more than a century (Wei et al., [1]; Yang et al., [2]-[4]). Being toxic and environmental restrictions may increase using of new reagents such as halogens (Gurung et al., [5]), thiocyanide (Kholmogorov et al., [6]), thiosulfate (Abbruzzese et al., [7]; Ficeriová et al., [8]; Hiskey and Atluri,

\footnotetext{
*Corresponding author.
}

How to cite this paper: Masoud, B., Amir, A. and Bahram, R. (2016) Investigate of Effective Factors on Extraction of Silver from Tailings of Lead Flotation Plant Using Thiourea Leaching. World Journal of Engineering and Technology, 4, 305-312. http://dx.doi.org/10.4236/wjet.2016.42031 
[9]) and thiourea are alternatives (Çelik, [10]; Chen et al., [11]; De Andrade Lima and Hodouin, [12]; Ficeriová et al., [13]; Hilson and Monhemius, [14]; Kononova et al., [15]; Lacoste et al., [16]; Li and Miller, [17]; Muir and Aylmore, [18]; Muñoz and Miller, [19]; Murthy, [20] [21]). Some of these methods are not only ecofriendly but also their leaching rates are higher than the conventional cyanidation method (Chen et al., [11]; Ficeriová et al., [16]; Agma et al., [22]; Groenewald, [23]).

According to aforementioned information, thiocyanide and thiourea receive much more attention than the others because thiourea has the low toxicity and kinetics higher (Wei et al., [1]; Kholmogorov et al., [6]; Çelik, [10]; Li and Miller, [17]; Agma et al., [22]; Li and Miller, [24] [25]) but not stable and can be converted to other complex compounds easily that neutralized the gold and silver also reduces the solving rate of them; (Jinshan et al., [26]; Kai et al., [27]). Likewise in comparison to thiourea, thiocyanide shows less toxicity, more stability but lower solubility rate (Barbosa, [28]-[32]). Another method is thiosulfate leaching that has been analyzed by Muir and Aylmore [18], Jeffrey et al. [33], Feng and Deventer [34]. The disadvantage of this process is oxidation of thiosulfate and turn into polythionats that will increase the consumption of reagent.

Thiourea leaching is done in acidic medium. If ferric ion used as an oxidizing agent in the following reaction occurs in solution (Gurung et al., [5]; Murthy et al., [21]; Kai et al. [27]; Almeidaand Amarante, [35]; Gonen et al., [36]; Jing-ying et al., [37]; Li et al., [38]; Ubaldini et al., [39]):

$$
\mathrm{Ag}+3 \mathrm{CS}\left(\mathrm{NH}_{2}\right)_{2}+\mathrm{Fe}^{3+} \rightarrow \mathrm{Ag}\left[\mathrm{Cs}\left(\mathrm{NH}_{2}\right)_{2}\right]^{3+}+\mathrm{Fe}^{2+}
$$

That the created complex is very strong and an oxidizing agent likes $\mathrm{H}_{2} \mathrm{O}_{2}$ or $\mathrm{Fe}_{2}\left(\mathrm{SO}_{4}\right)_{3}$ are needed to form it (Deschênes and Ghali, [40]). Formation mechanism of that complex contains two stages (TU: $\mathrm{H}_{2} \mathrm{~N}-\mathrm{CS}-\mathrm{NH}_{2}$ );

First step: a part of thiourea turns into Formamidine Disulfide (FDS) by an oxidizing agent.

Second step: FDS reacts with silver.

$$
\begin{gathered}
\left.2(\mathrm{TU})+2 \mathrm{Fe}^{+3} \rightarrow \begin{array}{l}
\left(\mathrm{NH}_{2}\right) \mathrm{CNHSSCNH}\left(\mathrm{NH}_{2}\right) \\
(\mathrm{FDS})
\end{array}\right) 2 \mathrm{Fe}^{2+}+2 \mathrm{H}^{+} \\
\mathrm{FDS}+2(\mathrm{TU})+2 \mathrm{Ag}+2 \mathrm{H}^{+} \rightarrow 2 \mathrm{Ag}(\mathrm{TU})_{2}^{+}
\end{gathered}
$$

The total reaction number (1) is obtained from the results of two parallel reactions, number (2) and (3). Moreover, FDS can be oxidized to the unwanted products that are clear in reaction number (4).

$$
\mathrm{FDS} \rightarrow \mathrm{TU}+\mathrm{H}_{2} \mathrm{NCN}+\mathrm{S}
$$

In this situation, TU consumption increases and the surface of thiourea is deactivated due to the formation of the final sulfide in reaction number (4) (Arriagada and Garcia, [41]; Gönen, [42]; Marsden and House, [43]).

In the current paper, all samples are taken from the old dam of tailings of Ravanj flotation plant and it is observed that the combination of silver is in the form of silver sulfide or argentite and it is about $30 \mathrm{ppm}$.

\section{Materials and Methods}

\subsection{Sample Characterization}

The samples taken from wells are drilled by powder drilling machine (RC 100) in tailings damp are mixed and the representative sample is provided for analysis. Sieve analysis and mineralogical studies of these samples are illustrated in Table 1, Table 2 and Figure 1.

As it is shown in the table, calcite and dolomite have the highest percentage of minerals in this sample which shows the carbonate nature of tailing ore. These studies showed silver is lucked with galena and the liberation degree of silver was about 53 microns.

\subsection{Preparation and Experimental Procedure}

Experiments were conducted in three dimensions, so that the samples were crushed by Laboratory wet rod mill $(\mathrm{D}=16 \mathrm{~cm}, \mathrm{~L}=35 \mathrm{~cm})$ for 15,20 and 25 minutes. The results are shown in Table 3.

The crush sample was divided into 500-g-smaller samples. All tests were done in Ravanj mine laboratory with its complete equipment. To reduce the $\mathrm{pH}$, thiourea leaching should be done in acidic medium so $30 \%$-sulfuric acid is used. At first, because the highest percentage of minerals in samples contain carbonate minerals so a heating stage up to $500^{\circ} \mathrm{C}$ was performed in furnace before leaching process (Laboratory furnace 2.5 lit). 
Table 1. Sieve analysis of representative sample from tailings of Ravanj flotation plant.

\begin{tabular}{|c|c|c|c|c|c|c|}
\hline Fraction of Dimensions & Weight & \multirow{2}{*}{$\begin{array}{c}\text { Weight } \\
\text { Percentage (\%) }\end{array}$} & $\begin{array}{c}\text { Cumulative } \\
\text { weight oversize }\end{array}$ & $\begin{array}{c}\text { Cumulative weight } \\
\text { undersize }\end{array}$ & Grade & Distribution \\
\hline$(\mu \mathrm{m})$ & (gram) & & (\%) & (\%) & (\%) & (\%) \\
\hline 212 & 11.9 & 6.24 & 6.24 & 93.76 & 15.5 & 5.2 \\
\hline-87 & 21.6 & 11.32 & 17.56 & 82.44 & 17.7 & 10.8 \\
\hline-50 & 27.8 & 14.57 & 32.13 & 67.87 & 19.8 & 15.6 \\
\hline-22 & 24 & 12.58 & 44.71 & 55.29 & 20.6 & 14 \\
\hline-53 & 105.5 & 55.29 & 100 & 0 & 18.2 & 54.4 \\
\hline total & 190.8 & 100 & & & & \\
\hline
\end{tabular}

Table 2. Mineralogical composition of representative sample from tailings of Ravanj flotation plant using XRD method.

\begin{tabular}{ccc}
\hline Minerals & Formula & Percent \\
\hline Calcite & $\mathrm{CaCO}_{3}$ & $\mathbf{3 2 . 2}$ \\
Dolomite & $\mathrm{CaMg}\left(\mathrm{CO}_{3}\right)_{2} / \mathrm{CaO} \cdot \mathrm{MgO} \cdot 2 \mathrm{CO}_{2}$ & $\mathbf{1 9 . 8}$ \\
Barite & $\mathrm{BaSO}_{4}$ & $\mathbf{1 0 . 2}$ \\
Quartz & $\mathrm{SiO}_{2}$ & $\mathbf{1 2 . 3}$ \\
Sphalerite & $\mathrm{ZnS}$ & $\mathbf{4 . 4}$ \\
Galena & $\mathrm{PbS}$ & $\mathbf{3 . 7}$ \\
Microcline & $\mathrm{KAlSi}_{3} \mathrm{O}_{8}$ & $\mathbf{1 1 . 3}$ \\
Illite-2 ITM2 RG & $\mathrm{K}_{0.7} \mathrm{Al}_{2.1}\left(\mathrm{Si}_{2} \mathrm{Al}_{4} \mathrm{O}_{10}(\mathrm{OH})_{2}\right.$ & $\mathbf{6 . 1}$ \\
\hline
\end{tabular}

Table 3. Grinding time of sample from tailings of Ravanj flotation plant.

\begin{tabular}{ccc}
\hline $\begin{array}{c}\text { Grinding time } \\
\text { (minute) }\end{array}$ & \multicolumn{2}{c}{ Particle diameter } \\
\cline { 2 - 3 } & $\mathbf{d 8 0}=\boldsymbol{\mu m}$ \\
20 & 75 & 53 \\
25 & $45 \quad 25$ \\
\hline
\end{tabular}

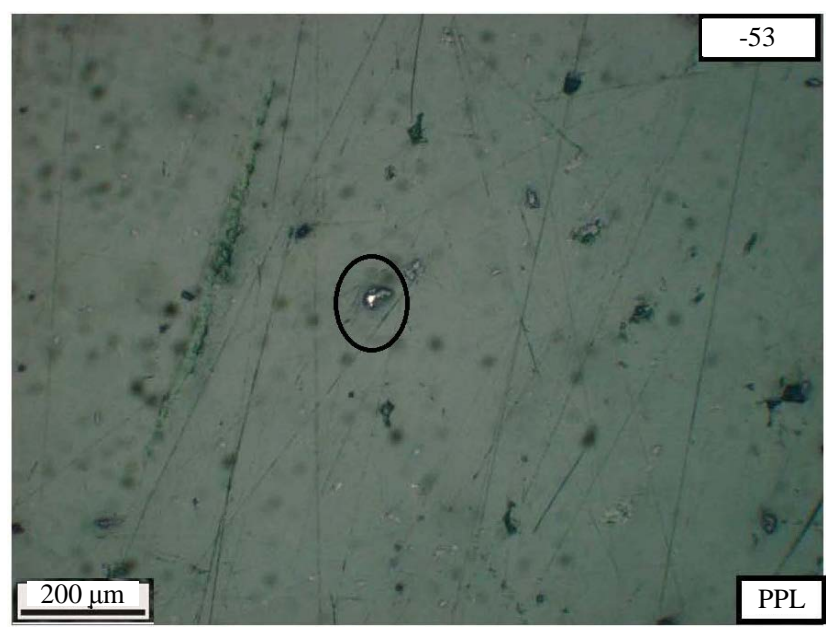

Figure 1. Mineralogical analysis with thin section. 
Main experiments were done in a beaker $(1000 \mathrm{~mL})$ with $40 \%$-solid concentration and constant speed stirrer (200 rpm) on a hot plate with an adjustable temperature. To prevent the possible changes in pulp density occurrence (because of the solution evaporate) distilled water was added to pulp during the experiments. The pulp was mixed with sulfuric acid (30\%) to reach $\mathrm{pH} 1$. The time needed for each test was at least 2 hours. Silver extracted from solution was analyzed by the atomic absorption spectrophotometry (Thermo model iCE 3300GF) in high temperature. The extraction of Ag was also calculated by using grades and leach solution volume and residue leach weight resulted from the experiments after decomposing the TU complex with $\mathrm{HNO}_{3}$ at high temperature.

\subsection{Design of Experiments}

In order to evaluate effect of variables and their interaction DX7 software and statistical design of the experiment were used. The advantages of designing such statistical experiments are lower related cost and reduced number of experiments (Fatahi et al., [44]; John Wiley \& Sons [45]). In this research incomplete factorial designing is recruited with regard to relation $\mathrm{N}=2^{\mathrm{n}-1}$ ( $\mathrm{N}=$ number of tests, $\mathrm{n}=$ number of variables). These variables such as TU concentration and iron(III) sulfate concentration, temperature and dimension were checked in three levels (low, middle and high). Table 4 shows the type and value of these factors. Table 4 shows the type and value of the variable.

\section{Results and Discussion}

Leaching tests were designed and done based on four variables and three repeating experiments as center point. The Table 5 shows the conditions and results of design in DX7.

The results show that the maximum recovery obtained in test number 5 in $80.8 \%$. The following equation is obtained from a mathematical model that can predict the amount of silver recovery by putting different variables (Equation (5)). In this model, the recovery percentage is predicted considering the effective variables ${ }^{1}$ :

$$
\text { Recovery }=+60.40000-8.08750 \mathrm{~B}+0.46000 \mathrm{C}
$$

In the above equation $\mathrm{B}=\mathrm{Fe}_{2}\left(\mathrm{SO}_{4}\right)_{3}$ and $\mathrm{C}=$ Temperature ${ }^{2}$. By using ANOVA analysis, the effective factors are determined which are available in Table 6.

If the F-value of the variable is higher than F-value of the model, so it shows the high effect of that variable with confidence percentage of 95\%. The results show that iron(III) sulfate concentration and temperature are effective on Ag recovery. The most effective factor on Ag recovery is iron(III) sulfate concentration. Figure 2 shows the normal plot curve which confirmed statistical analysis.

The effect of iron(III) sulfate and temperature is shown in Figure 3 and Figure 4. As can be seen in the figure, increasing the iron(III) sulfate concentration from 1 to $3 \mathrm{~kg} / \mathrm{m}^{3}$ leads to reduction of recovery from $73 \%$ to $57 \%$. This reduction is due to the combination of some iron(III) sulfate with thiourea and reduction of thiourea concentration consequently. Solve this problem by adding new thiourea or reduce iron(III) sulfate concentration is possible. It seems optimizing iron(III) sulfate concentration to avoid increasing the cost more reasonable ${ }^{3}$.

Also Increasing temperature from $30^{\circ} \mathrm{C}$ to $60^{\circ} \mathrm{C}$ increased the silver recovery rate. Higher temperatures speed up decomposition of thiourea and if the main variables such as the concentration of Iron(III) sulfate and thiourea be appropriate thiourea will form a complex with silver normally.

Table 4. Coded and actual levels of independent variables used in factorial design.

\begin{tabular}{cccccc}
\hline \multirow{2}{*}{ variable } & symbol & Unit & \multicolumn{3}{c}{ Coded variable level } \\
\cline { 4 - 6 } & & & Low & Center & High \\
\hline Thiourea & $\mathrm{Kg} / \mathrm{M}^{3}$ & 1 & 3 & 5 \\
$\mathrm{Fe}_{2}\left(\mathrm{SO}_{4}\right)_{3}$ & $\mathrm{~K}$ & $\mathrm{Kg} / \mathrm{M}^{3}$ & 1 & 2 & 3 \\
Temperature & $\mathrm{C}$ & ${ }^{\circ}$ & 30 & 45 & 60 \\
Size & $\mathrm{D}$ & $\boldsymbol{\mu m}$ & 45 & 60 & 75 \\
\hline
\end{tabular}

\footnotetext{
${ }^{1}$ Obtained DX7 software.

${ }^{2}$ Table 4.

${ }^{3}$ Refer to Introduction, Equation (2).
} 
Table 5. Factorial design and experimental results thiourea leaching experiments.

\begin{tabular}{|c|c|c|c|c|c|c|c|c|c|}
\hline \multirow{2}{*}{ Run No } & \multicolumn{4}{|c|}{ Coded level of variables } & \multicolumn{4}{|c|}{ Actual level of variables } & \multirow{2}{*}{$\begin{array}{c}\text { Response } \\
(\%)\end{array}$} \\
\hline & A & B & $\mathrm{C}$ & $\mathrm{D}$ & A & B & $\mathrm{C}$ & $\mathrm{D}$ & \\
\hline 1 & -1 & -1 & -1 & -1 & 1 & 1 & 30 & 45 & 68.25 \\
\hline 2 & 1 & -1 & -1 & 1 & 5 & 1 & 30 & 75 & 64.7 \\
\hline 3 & -1 & 1 & -1 & 1 & 1 & 3 & 30 & 75 & 48.25 \\
\hline 4 & 1 & 1 & -1 & -1 & 5 & 3 & 30 & 45 & 50.9 \\
\hline 5 & -1 & -1 & 1 & 1 & 1 & 1 & 60 & 75 & 80.8 \\
\hline 6 & 1 & -1 & 1 & -1 & 5 & 1 & 60 & 45 & 78.3 \\
\hline 7 & -1 & 1 & 1 & -1 & 1 & 3 & 60 & 45 & 65.8 \\
\hline 8 & 1 & 1 & 1 & 1 & 5 & 3 & 60 & 75 & 62.4 \\
\hline 9 & 0 & 0 & 0 & 0 & 3 & 2 & 45 & 60 & 70.2 \\
\hline 10 & 0 & 0 & 0 & 0 & 3 & 2 & 45 & 60 & 69.6 \\
\hline 11 & 0 & 0 & 0 & 0 & 3 & 2 & 45 & 60 & 70.8 \\
\hline
\end{tabular}

Table 6. Results obtained from the ANOVA analysis.

\begin{tabular}{|c|c|c|c|c|c|c|}
\hline Source & Sum of squares & Df & Mean square & F-value & p-value prob $>$ F & Note \\
\hline Model & 904.14 & 2 & 452.07 & 154.45 & $<0.0001$ & significant \\
\hline $\mathrm{B}-\mathrm{Fe}_{2}\left(\mathrm{So}_{4}\right)_{3}$ & 523.26 & 1 & 523.26 & 178.77 & $<0.0001$ & \\
\hline C-temp & 380.88 & 1 & 380.88 & 130.13 & $<0.0001$ & \\
\hline Curvature & 60.71 & 1 & 60.71 & 20.74 & 0.0026 & significant \\
\hline Residual & 20.49 & 7 & 2.93 & & & \\
\hline Lack of Fit & 19.77 & 5 & 3.95 & 10.98 & 0.0856 & not significant \\
\hline Pure Error & 0.72 & 2 & 0.36 & & & \\
\hline Cor Total & 985.34 & 10 & & & & \\
\hline
\end{tabular}

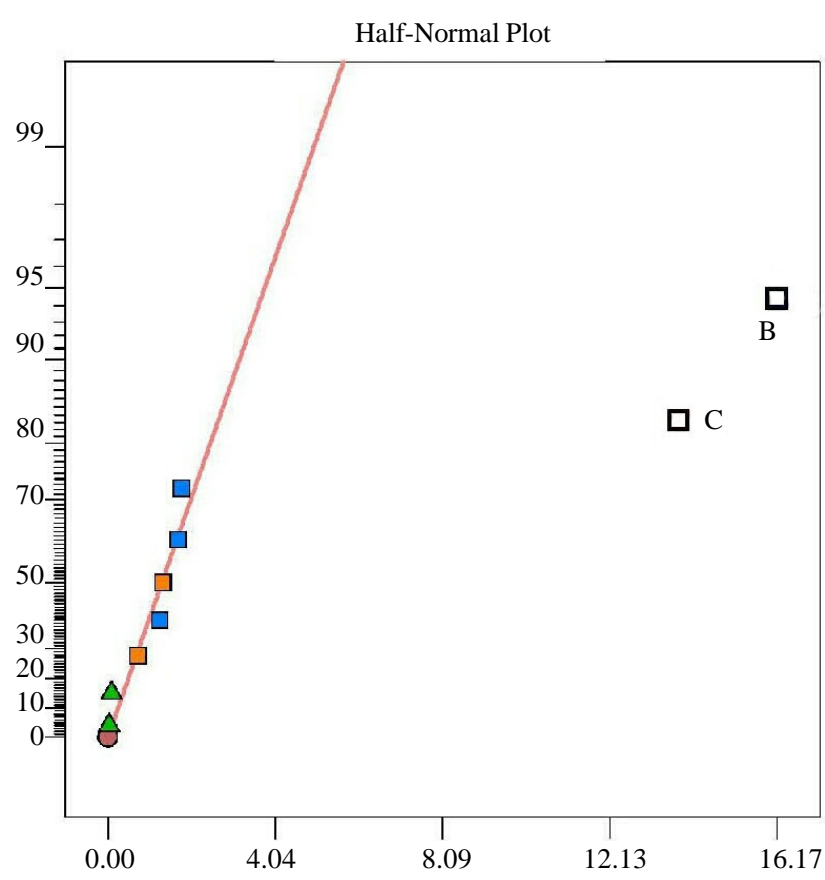

Figure 2. Half normal plot curve. 


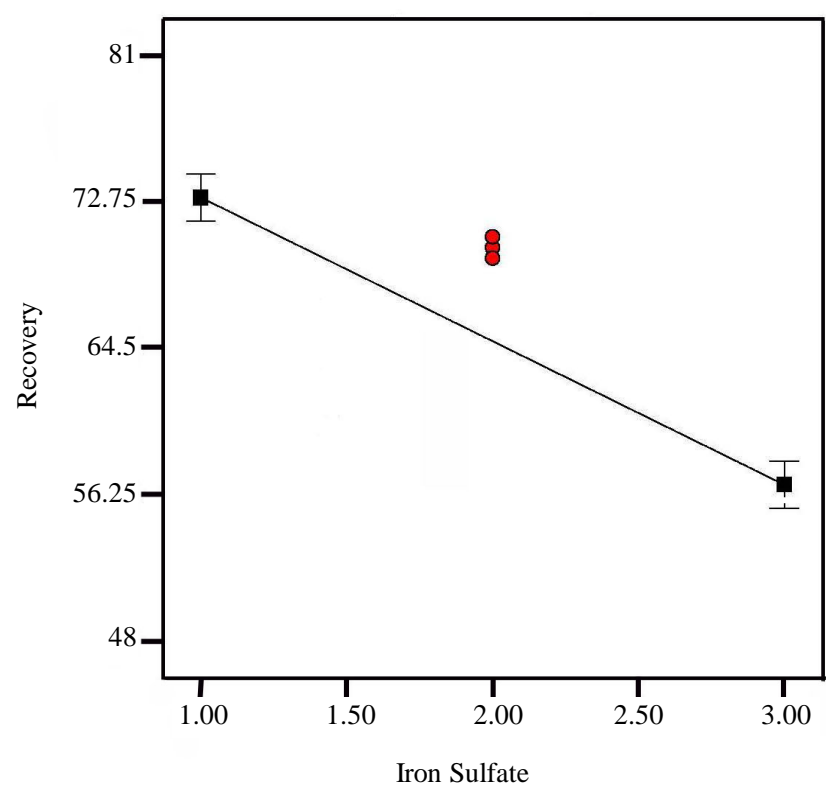

Figure 3. Influence of $\mathrm{Fe}_{2}\left(\mathrm{So}_{4}\right)_{3}$ concentration on Ag recovery.

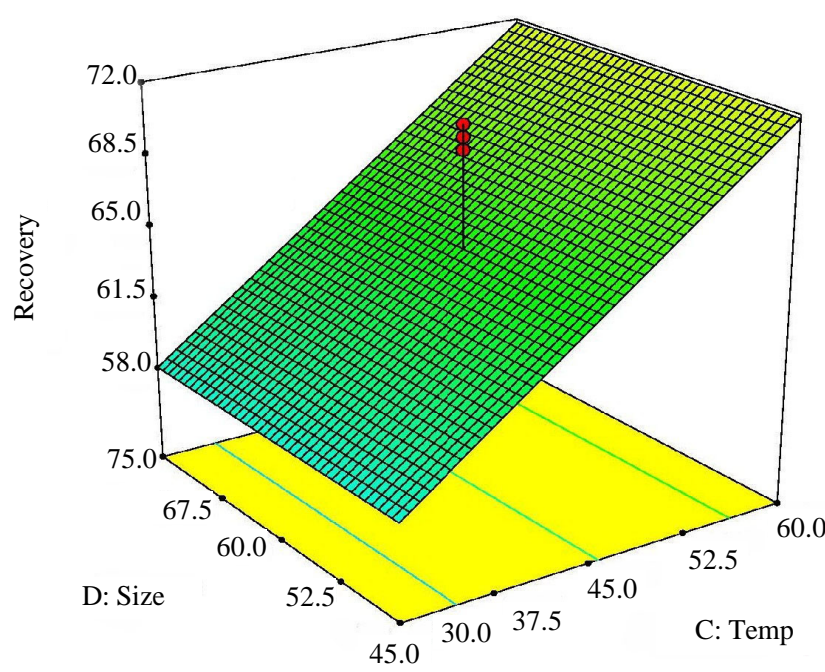

Figure 4. Influence of temperature on Ag recovery.

\section{Conclusion}

Mineralogical studies of representative sample from tailings of Ravanj flotation plant indicated silver was lucked with galena and showed that it contained $30 \mathrm{ppm}$ silver and the highest percentage of minerals in it was carbonate minerals that increased the consumption of sulfuric acid. So acidic leaching would not be economical in these samples. For this reason, a heating stage up to $500^{\circ} \mathrm{C}$ was performed before main tests. Modeling and optimization, results analysis and experiments design process were done by DX7 software. ANOVA results indicated that temperature increase and Iron(III) sulfate concentration decrease were the effective factors on the silver recovery. Maximum recovery of silver occurred in size of 75 microns with $1 \mathrm{~kg} / \mathrm{m}^{3}$ thiourea and $1 \mathrm{~kg} / \mathrm{m}^{3}$ iron(III) sulfate in $60^{\circ} \mathrm{C}$ for 2 hours.

\section{References}

[1] Wei, D.W., Chai, L.Y. and Ichino, R. (1999) Gold Leaching in an Alkaline Thiourea Solution. Journal of the Electrochemical Society, 146, 559-563. http://dx.doi.org/10.1149/1.1391643 
[2] Yang, X., Moats, M.S. and Miller, J.D. (2010) Gold Dissolution in Acidic Thiourea and Thiocyanate Solutions. Electrochimica Acta, 55, 3643-3649. http://dx.doi.org/10.1016/j.electacta.2010.01.105

[3] Yang, X., Moats, M.S. and Miller, J.D. (2010) The Interaction of Thiourea and Formamidine Disulfide in the Dissolution of Gold in Sulfuric Acid Solutions. Minerals Engineering, 23, 698-704. http://dx.doi.org/10.1016/j.mineng.2010.04.006

[4] Yang, X., Moats, M.S. and Miller, J.D. (2010) Using Electrochemical Impedance Spectroscopy to Investigate Gold Dissolution in Thiourea and Thiocyanate Acid Solutions. ECS Transactions, 28, 213-222.

[5] Gerung, M., Babu Adhikari, B., Kawakita, H., Ohto, K., Inoue, K. and Alam, S. (2013) Recovery of Gold and Silver from Spent Mobile Phones by Means of Acidic Thiourea Leaching Followed by Adsorption Using Biosorbent Prepared from Persimmon Tannin. Hydrometallurgy, 133, 84-86. http://dx.doi.org/10.1016/j.hydromet.2012.12.003

[6] Kholmogorov, A.G., Kononova, O.N., Pashkov, G.L. and Kononov, Y.S. (2002) Thiocyanate Solutions in Gold Technology. Hydrometallurgy, 64, 43-48. http://dx.doi.org/10.1016/S0304-386X(02)00005-1

[7] Abbruzzese, C., Fornari, P., Mesidda, R., Veglió, F. and Ubaldini, S. (1995) Thiosulphate Leaching for Gold Hydrometallurgy. Hydrometallurgy, 39, 265-276. http://dx.doi.org/10.1016/0304-386X(95)00035-F

[8] Ficeriová, J.P., Baláž, P. and Villachica, C.L. (2005) Thiosulfate Leaching of Silver, Gold and Bismuth from a Complex Sulfide Concentrate. Hydrometallurgy, 77, 35-39. http://dx.doi.org/10.1016/j.hydromet.2004.09.010

[9] Hiskey, J.B. and Atluri, V.P. (1988) Dissolution Chemistry of Gold and Silver in Different Lixiviants. Mineral Processing and Extractive Metallurgy Review, 4, 95-134. http://dx.doi.org/10.1080/08827508808952634

[10] Çelik, H. (2004) Extraction of Gold and Silver from a Turkish Gold Ore through Thiourea Leaching. Minerals and Metallurgical Processing, 21, 144-148.

[11] Chen, C.K., Lung, T.N. and Wan, C.C. (1980) A Study of the Leaching of Gold and Silver by Acidothioureation. Hydrometallurgy, 5, 207-212. http://dx.doi.org/10.1016/0304-386X(80)90039-0

[12] De Andrade Lima, L.R.P. and Hodouin, D. (2005) A Lumped Kinetic Model for Gold Ore Cyanidation. Hydrometallurgy, 79, 121-137. http://dx.doi.org/10.1016/j.hydromet.2005.06.001

[13] Ficeriová, J., Baláž, P., Dutková, E. and Gock, E. (2008) Leaching of Gold and Silver from Crushed Au-Ag Wastes. Chemistry Central Journal, 2, 6-9. http://dx.doi.org/10.2174/1874123100802010006

[14] Hilson, G. and Monhemius, A.J. (2006) Alternatives to Cyanide in the Gold Mining Industry: What Prospects for the Future. Journal of Cleaner Production, 14, 1158-1167. http://dx.doi.org/10.1016/j.jclepro.2004.09.005

[15] Kononova, O.N., Kholmogorov, A.G., Danilenko, N.V., Goryaeva, N.G., Shatnykh, K.A. and Kachin, V.S. (2007) Recovery of Silver from Thiosulfate and Thiocyanate Leach Solutions by Adsorption on Anion Exchange Resins and Activated Carbon. Hydrometallurgy, 88, 189-195. http://dx.doi.org/10.1016/j.hydromet.2007.03.012

[16] Lacoste-Bouchet, P., Deschênes, G. and Ghali, E. (1998) Thiourea Leaching of Copper-Gold Ore Using Statistical Design. Hydrometallurgy, 47, 189-203. http://dx.doi.org/10.1016/S0304-386X(97)00043-1

[17] Li, J. and Miller, J.D. (2002) Thiocyanate Research Program. Part I. Thermodynamic Analysis: Electrochemical Stability Diagrams for the Thiocyanate System. Research Progress Report to the Newmont Metallurgical Services, University of Utah, Salt Lake City.

[18] Muir, D.M. and Aylmore, M.G. (2005) Thiosulfate as an Alternative Lixiviant to Cyanide for Gold Ores. In: Adams, M.D., Ed., Advances in Gold Ore Processing, Elsevier, Amsterdam, 541-560. http://dx.doi.org/10.1016/S0167-4528(05)15022-4

[19] Muñoz, G.A. and Miller, J.D. (2000) Noncyanide Leaching of an Auriferous Pyrite ore from Ecuador. Minerals and Metallurgical Processing, 17, 198-204.

[20] Murthy, D.S.R. and Prasad, P.M. (1996) Leaching of Gold Silver from Miller Process Dross through Non-Cyanide Leachants. Hydrometallurgy, 42, 27-33. http://dx.doi.org/10.1016/0304-386X(95)00049-M

[21] Murthy, D.S.R., Kumar, V. and Rao, K.V. (2003) Extraction of Gold from an Indian Low Grade Refractory Gold Ore through Physical Beneficiation and Thiourea Leaching. Hydrometallurgy, 68, 125-130. http://dx.doi.org/10.1016/S0304-386X(02)00197-4

[22] Agma, E., Arslan, F. and Wuth, W. (1993) Silver Extraction from a Refractory Type Ore by Thiourea Leaching. Hydrometallurgy, 34, 263-274. http://dx.doi.org/10.1016/0304-386X(93)90040-K

[23] Groenewald, T. (1976) The Dissolution of Gold in Acidic Solutions of Thiourea. Hydrometallurgy, 1, 277-290. http://dx.doi.org/10.1016/0304-386X(76)90004-9

[24] Li, J. and Miller, J.D. (2002) Reaction Kinetics for Gold Dissolution in Acid Thiourea Solution Using Formamidine Disulfide as Oxidant. Hydrometallurgy, 63, 215-223. http://dx.doi.org/10.1016/S0304-386X(01)00212-2

[25] Li, J. and Miller, J.D. (2006) A Review of Gold Leaching in Acid Thiourea Solutions. Mineral Processing and Extrac- 
tive Metallurgy Review: An International Journal, 27, 177-214. http://dx.doi.org/10.1080/08827500500339315

[26] Li, J.H., Sadegh Safarzadeh, M., Moats, M., Miller, J., Marc Levier, K., Dietrich, M. and Wan, R. (2012) Thiocyanate Hydrometallurgy for the Recovery of Gold. Part II: The Leaching Kinetics. Hydrometallurgy, 113-114, 10-18. http://dx.doi.org/10.1016/j.hydromet.2011.11.007

[27] Kai, T., Hagiwara, T., Haseba, H. and Takahashi, T. (1997) Reduction of Thiourea Consumption in Gold Extraction by Acid Thiourea Solutions. Industrial \& Engineering Chemistry Research, 36, 2757-2759. http://dx.doi.org/10.1021/ie970064r

[28] Barbosa-Filho, O. (1991) Thiocyanate Leaching of Gold. Ph.D. Thesis, Imperial College, University of London, London.

[29] Barbosa-Filho, O. and Monhemius, A.J. (1994) Leaching of Gold in Thiocyanate Solutions—Part 1: Chemistry and Thermodynamics. Transactions of the Institutions of Mining and Metallurgy: Section C, 103, C105-C110.

[30] Barbosa-Filho, O. and Monhemius, A.J. (1994) Leaching of Gold in Thiocyanate Solutions-Part 2: Redox Processes in Iron(III)-Thiocyanate Solutions. Transactions of the Institutions of Mining and Metallurgy: Section C, 103, C111C116.

[31] Barbosa-Filho, O. and Monhemius, A.J. (1994) Leaching of Gold in Thiocyanate Solutions-Part 3: Rates and Mechanism of Gold Dissolution. Transactions of the Institutions of Mining and Metallurgy: Section C, 103, C117-C125.

[32] Barbosa-Filho, O. and Monhemius, A.J. (1988) Thermochemistry of Thiocyanate Systems for Leaching Gold and Silver Ores. In: Jha, M.C. and Hill, S.D., Eds., Precious Metals 89, The Minerals, Metals and Materials Society, Warrendale, 307-339.

[33] Jeffrey, M., Heath, J., Hewitt, D., Brunt, S. and Dai, X. (2008) A Thiosulfate Process for Recovering Gold from Refractory Ores Which Encompasses Pressure Oxidation, Leaching, Resin Adsorption, Elution and Electro Winning. In: Young, C.A., Taylor, P.R., Anderson, C.G. and Choi, Y., Eds., Hydrometallurgy 2008, Proceedings of the 6th International Symposium, Phoenix, 824-836.

[34] Feng, D. and van Deventer, J.S.J. (2011) Thiosulphate Leaching of Gold in the Presence of Carboxymethyl Cellulose (CMC). Minerals Engineering, 24, 115-121. http://dx.doi.org/10.1016/j.mineng.2010.10.007

[35] Almeida, M. and Amarante, M.A. (1994) Leaching of a Silver Bearing Sulphide By-Product with Cyanide, Thiourea and Chloride Solutions. Minerals Engineering, 262-271.

[36] Gonen, N., Korpe, E., Yildirim, M.E. and Selengil, U. (2007) Leaching and CIL Processes in Gold Recovery from Refractory Ore with Thiourea Solutions. Minerals Engineering, 20, 559-565. http://dx.doi.org/10.1016/j.mineng.2006.11.003

[37] Li, J.-Y., Li, X.X. and Liu, W.-Q. (2012) Thiourea Leaching Gold and Silver from the Printed Circuit Boards of Waste Mobile Phones. Waste Management, 32, 1209-1212. http://dx.doi.org/10.1016/j.wasman.2012.01.026

[38] Li, J., Lu, H., Guo, J., Xu, Z. and Zhou, Y. (2007) Recycle Technology for Recovering Resources and Products from Waste Printed Circuit Boards. Environmental Science \& Technology, 41, 1995-2000. http://dx.doi.org/10.1021/es0618245

[39] Ubaldini, S., Fornari, P., Massidda, R. and Abbruzzese, C. (1998) An Innovative Thiourea Gold Leaching Process. Hydrometallurgy, 48, 113-124. http://dx.doi.org/10.1016/S0304-386X(97)00076-5

[40] Deschênes, G. and Ghali, E. (1988) Leaching of Gold from a Chalcopyrite Concentrate by Thiourea. Hydrometallurgy, 20, 179-202. http://dx.doi.org/10.1016/0304-386X(88)90051-5

[41] Arriagada, R. and Garcia, R. (1997) Retention of Aurocyanide and Thiourea-Gold Complexes on Activated Carbons Obtained from Lignocellulosic Materials. Hydrometallurgy, 46, 171-180. http://dx.doi.org/10.1016/S0304-386X(97)00010-8

[42] Gönen, N. (2003) Leaching of Finely Disseminated Gold Ore with Cyanide and Thiourea Solutions. Hydrometallurgy, 69, 169-176. http://dx.doi.org/10.1016/S0304-386X(03)00005-7

[43] Marsden, J. and House, I. (1991) The Chemistry of Gold Extraction. Prentice-Hall, Upper Saddle River, 400 p.

[44] Fatahi, M., Noaparast, M. and Shafaei Seyyed, Z. (2014) Nickel Extraction from Low Grade Laterite by Agitation Leaching at Atmospheric Pressure. International Journal of Mining Science and Technology, 24, 543-548.

[45] Dean, A.M. (1999) Design and Analysis of Experiments. John Wiley \& Sons Inc., Arizona. 